\title{
Tragedy of Rural Youth Out-Migration and Its Socio-Economic Consequences in Lemo Woreda of Hadiya Zone, Southern Ethiopia
}

\author{
Fikreab Mekebo $^{1} \quad$ Asrat Worku ${ }^{2}$ \\ Department of Rural development and Agricultural Extension, College of Agriculture, Wolaita Sodo University, \\ Ethiopia \\ P.O. Box: 138, Wolaita Sodo University, Ethiopia
}

\begin{abstract}
Out-migration affects the socio- economic situation of the youths, families and people at large in a country. However, rural youth out-migration in Ethiopia in general and Hadiya Zone specifically has become more common business. Hence, this study was conducted to investigate the causes and consequences of youth out-migration from Lemo woreda of Hadiya zone in Southern Ethiopia to South Africa. Primary and secondary sources of data were used. Primary information collected from returnees and families of migrants through interview schedule, FGDs and KI guidelines. 100 respondents were selected for survey questionnaire by purposive sampling technique. Descriptive statistical method is employed to analyze quantitative data by using SPSS whereas the qualitative data was analyzed using description. The result of the study reported that in Lemo woreda out migration is dominated by young aged 23-29. The largest proportion of youth migrants have faced imprisonment, hunger and social crises, vulnerability to disease, and loss of life during traveling to South Africa, Dependency on remittance, low educational achievement, loss of life, and shortage of labor force in the origin are among the problems due to migration. Based on these findings recommendations are given to concerned bodies to give due attention to help youths to study and create better job opportunities in their origin.
\end{abstract}

Keywords: Ethiopia, Youth, out-migration, returnees

DOI: $10.7176 / \mathrm{JESD} / 11-17-02$

Publication date:September $30^{\text {th }} 2020$

\section{Introduction}

Migration is defined as changing the place of residence by crossing a specified administrative or political boundary. It is movement of a person or a group of persons, either across an international border, or within a State (IOM, 2014). As of 2017, the number of international migrants worldwide stood at almost 258 million (or 3.4 percent of the world's population). According to UN Population Division estimates 14\% of the migrants are below 20 years old youths (Wilkinson, 2015; Becky C. and Brigitte R., 2016; Castles H., de Haas and Mark J., 2014).

Youth migration is a form of productive labor migration and the people most likely to leave are those of working age and students. Unfortunately, many young migrants frequently get trapped in exploitative and abusive jobs, including forced labor. And too often, they - like other migrants - become scapegoats for the shortcomings of economic and social systems (Habte, 2015; ILO, 2016). According to the International Labor Organization in 2018, the youth unemployment rate was 10.9\% in Sub-Saharan Africa (Assefa et al, 2015; ILO, 2018).

Each year, thousands of young Ethiopians risk their lives in an attempt to reach South Africa, where they hope to establish better lives for themselves and their families. Migrants often sacrifice their life. There were 614,000 Ethiopians in modern slavery both within Ethiopia and abroad (Balayneh, 2016; Habte, 2015). In Ethiopia, the unemployment rate stands at 24 Furthermore, low incomes, unemployment, underemployment and poor working conditions are highest amongst youths, while about $71 \%$ population is under the age of 30 years (FAO, 2018).

In Ethiopia, the problem is widely observed in two zones of the southern parts, namely in Hadya and Kambata-Tambaro Zones (Sinedu, 2009; Habte, 2015). Most of the young adults who move irregularly to South Africa had suffered several problems - among them are being smuggled, physical abuse, human right violation, death as well as robbery (Teshome et al., 2013). However, the problem still needs investigating the trend specific to the woreda and update the risk in the zone. Hence, this study focuses on investigating causes and consequences of youth migration from rural area of Lemo woreda in Hadiya Zone of Southern Ethiopia to South Africa.

\section{Statement of the problem}

Recently, many rural youths of Lemo woreda of Hadiya zone have left their origin and migrate to different countries by the push and pull factors or support of smugglers. It has been estimate that about 120,000 Ethiopians work and live in South Africa, and the flow has dramatically increased as a result of the effective operation of migrant smuggling networks. However, since the majority is irregular migrants, they are invisible, and nobody knows the true figures (Adugna, 2019, Assefa et al, 2015). 
According to the report of Hadiya zone Human Resource and Social Affairs department, it is estimated that, totally 61,148 youths (female 13,452 and 47,698 male) have migrated illegally to South Africa from the zone in 6 years period from 2013 to 2018 . From Lemo woreda a total of 8,266 people (2,066 female and 6,200 male) within the same year interval. This irregular migration has high consequence in the life of the youth migrants (Hadiya Zone Human Resource and Social Affairs Department, 2018).

It has visible negative consequences in Lemo woreda. Youths become less educated and both teachers and students from the grade levels of 7-12 move to South Africa by dropping out their work and education. Students even children's dream of Lemo woreda is to migrate to the South Africa. The youth migration has contributed to the school dropout in the area. Based on the South Nations, Nationalities and Peoples Region Education Bureau data of 2009/2017 E.C, school dropout rate was 13.8\% in Hadiya zone, which was the highest from all zones in the region and was well above the regional average 10\% (SNNPR Education Bureau, 2009/2017).

Hence, motivation of the researcher is to come up with scientific findings which would have policy implication and could be baseline for local government authorities' priority setting to rural youth.

\subsection{Objectives of the Study}

This study was conducted to specifically address the following objectives.

- identify causes initiate rural youths to out-migrate to the Republic of South Africa

- identify consequences of rural youth out-migration on the migrants, their families and the community at large

\section{Youth migration in Ethiopia}

UN defines youth as someone aged 15-24 years (Castles H., de Haas and Mark J., 2014; UN, 2016). For the purpose of this paper the researcher used the definition of Ethiopian National Youth policy. It defines youth as those aged between 15-29 years (Ethiopian Youth National policy, 2004).

Most migration studies in Ethiopia are concerned about internal migration and not much is done on international migration (Habte, 2015; Adamnesh, 2006). Ethiopia is one of the poorest countries in the world. Ethiopia faces complex challenges of food insecurity, overpopulation, drought, political instability, and ethnic conflict. There are currently 614,000 Ethiopians in modern slavery which ranks Ethiopia fifth in the world (IOM, 2014).

South Africa has emerged as an important destination of Ethiopian labor power migrants. Recently, there has been enormous amount of labor migrants from Hadiya and Kembata -Tembaro zones to the South Africa (Teshome et al., 2013). Most of the young who migrate to the South Africa are economically active and are heading in pursuit of "dream" of capturing the green pasture there. This problem is widely observed in the Southern parts of Ethiopia, Particularly in Kembata-Tembaro and Hadiya zones (Habte, 2015; IOM, 2013).

\section{Effects of migration}

Rural youths' out-migration related implications are many and multi-faced (Mwiti, 2015). Studies have demonstrated that Ethiopian migrants generally spend 1-3 years in neighboring countries before immigrating to where they are migrating. Ethiopian refugees residing in refugee camps in neighboring countries may also receive resettlement in other countries further abroad (Teshome et al., 2013; Emerta et al, 2010). Most of the young adults who migrate to the South Africa are economically active and are heading in pursuit of dream of capturing the green pasture there (Assefa et al 2015; Frouws, B., 2015).

According to the report of Hadiya zone Human resource and social affairs department report 2018, totally 61,148 youths (female 13,452 and 47,698 male) have been migrated illegally to South Africa from the zone in 6 years period from 2013 to 2018 . From Lemo woreda a total of 8,266 people (2,066 female and 6,200 male) within the same year interval.

\section{Research Methodology \\ Description of the study area}

Lemo woreda is located in Hadiya Zone of South Nations and Nationalities and People Regional State (SNNPR). The town of Hosanna is surrounded by Lemo. The woreda has a total of 33 rural and 2 urban Kebeles. According to SNNPR, BoFED, Annual Statistical Abstract 2009 EC 2014/2017 the total population of the Woreda is 160,620, of which 81,161 are female. The average family size of the woreda is 6 and the average land holding size is 0.75 ha per Household.

\section{Research Design}

Cross sectional research design with descriptive survey was employed while conducting this research. 


\section{Sampling techniques and sample Size determination}

The researcher employed purposive sampling technique. This woreda was selected due to the intensity of the problem. From this Woreda, the researcher selected four kebeles purposively. These kebeles are known by intensity of youth out migration by the woreda and the community. The selected kebeles were Lereba, Lisana, Hayse and Belesa. From the total population of the four kebeles there are about 1,700 youth migrants including returned migrants and sample size was 100 individuals by using the formula $\mathrm{n}=\mathrm{N} /\left(1+\mathrm{Ne}^{2}\right)$

Where $\mathrm{N}=$ Population size Household Heads); $\mathrm{n}=$ Sample size (to be interviewed); and $\mathbf{e}^{\mathbf{2}}=$ Margin of error. The margin of error $(\mathrm{e}=0.1)$ and calculated as follows:

$$
\mathrm{n}=1,700 /[1+1,700(0.1 \times 0.1)]
$$

$\mathrm{n}=1,700 / 17.01 \mathrm{n}=99.94$, approximately around 100 individuals as mentioned above.

Among the respondents, 60 were migrants' family members and 40 were returnee returnees. A total of 32 participants were selected for focus group discussions in purposive sampling technique. One FGD was conducted at each kebele level with 8 participants. The composition was two FGDs with families of out migrant in two kebeles and two FGDs with returnees in two kebeles. Key informants include elders, head of Hadiya Zone Lour and social Affairs, Lemo woreda trade and industry office and head of Lemo woreda Youth and sport office were participated in the study.

\section{Methods of data collection}

For the purpose of this study, the primary data has been collected using interview schedule and key informants' interviews and focus group discussion tools on the other hand.

\section{Methods of data analysis}

Simple descriptive statistics (percentage and frequency) for quantitative data and narration have been used to analyze data generated.

\section{Result and Discussion}

Demographic characteristics of the respondents

The table 1 below, we understand that $85 \%$ of out migrants' families were male and $15 \%$ female. Table 1. Sex profile of respondents

\begin{tabular}{lllll}
\hline Variables & \multicolumn{2}{c}{ Out-migrant } & \multicolumn{2}{c}{ Return migrant } \\
\hline Sex & Frequency & Percent & Frequency & Percent \\
\cline { 2 - 5 } Male & 51 & 85 & 26 & 65 \\
Female & 9 & 15 & 14 & 35 \\
\hline Total & 60 & 100 & 40 & 100 \\
\hline
\end{tabular}

As shown below, the large proportion of out migrants' families are in age category above 40 (83\%), followed by $30-40(17 \%)$.

Table 2. Age profile of respondents

\begin{tabular}{lllll}
\hline Variables & Out-migrant & & Return migrant & \\
\hline Age & Frequency & Percent & Frequency & Percent \\
$15-22$ & - & - & 15 & 38 \\
$23-29$ & - & - & 25 & 62 \\
$30-40$ & 10 & 17 & - & - \\
$40-45$ & 50 & 83 & - & - \\
Total & 60 & 100 & 40 & 100 \\
\hline
\end{tabular}

The result of the study shows that the migration tendency in the study area is dominated by the single migratory group of out- migrant about (65\%) followed by married $(35 \%)$.

Table 3. Marital status of the respondents

\begin{tabular}{lllll}
\hline Variables & \multicolumn{2}{c}{ Out-migrant } & \multicolumn{2}{c}{ Return migrant } \\
\hline Marriage & Frequency & Percent & Frequency & Percent \\
\cline { 2 - 5 } Single & - & - & 26 & 65 \\
Married & 52 & 87 & 14 & 35 \\
Divorced & 8 & 13 & - & 100 \\
\hline Total & 60 & 100 & 40 & \\
\hline
\end{tabular}

Sex selectivity of migration of youth is mainly attributable to the type of work available in South Africa as well as the difficulty of the journey, which on the average takes over two months. This also supported by other finding conducted in the area (Teshome et al., 2010). The migration decision of an individual is also influenced by marital status. The migration of young adult to South Africa is age selective. 
Socio- Economic Characteristics of the Respondents

Table 4. Level of education of respondents

\begin{tabular}{lllll}
\hline Variable & Out-migrants & & Returnees \\
\hline Education & Frequency & Percent & Frequency & Percent \\
\cline { 2 - 5 } Can't read and write & 7 & 11.6 & - & - \\
Attended primary school (grade 1-8) & 22 & 36.6 & 18 & 45 \\
Attended secondary school (grade 9-12) & 20 & 33.3 & 16 & 40 \\
Completed Diploma & 7 & 11.6 & 6 & 15 \\
Completed BA/BSc Degree & 4 & 6.6 & - & - \\
Total & 60 & 100 & 40 & 100 \\
\hline
\end{tabular}

The result in above table shows from the families of out migrants, the higher rate were primary students $(22 \%)$ followed by secondary about (20\%), diploma (7\%), cannot read and write (7\%) and first degree and above (4\%). The level of education for most returnee is primary school students $(45 \%)$ followed by secondary $(40 \%)$ and the better educated are only $(6 \%)$.

\section{Occupation of respondents before migration}

The large percent of migrants $49 \%$ were unemployed before they migrate. According to the FGD participants reported most of the youths who were participating on farming activities had no their own farming land but it belongs to their parents or they work for equal share with others.

Table 5. Occupation type of respondents

\begin{tabular}{lclcc}
\hline Variable & Out-migrants & \multicolumn{2}{c}{ Returnees } & \\
\hline Occupation & Frequency & Percent & Frequency & Percent \\
\cline { 2 - 5 } Employee under government or NGO & 5 & 8.3 & 2 & 5 \\
Farming & 17 & 28.3 & 4 & 10 \\
Petty trader & 7 & 11.7 & 5 & 12 \\
Employee under private sector & 7 & 11.7 & 4 & 10 \\
Unemployed & 24 & 40 & 25 & 63 \\
Total & 60 & 100 & 40 & 100 \\
\hline
\end{tabular}

\section{Transportation during migration}

Large proportion of the youth migrants $79 \%$ used by car and foot and the $21 \%$ of the youths traveled through air plane \& car. The cars are containers/lorry only for goods/materials. The migrants are also using the foot transportation through fearful and troubling forests.

Table 6. Transportation during migrating

\begin{tabular}{lllll}
\hline Variables & Out-migrant & \multicolumn{2}{l}{ Return migrant } \\
\hline Means of transportation & Frequency & Percent & Frequency & Percent \\
\cline { 2 - 5 } Airplane and car & - & - & 26 & 65 \\
Car and foot & 9 & 15 & 12 & 21 \\
Divorced & 51 & 85 & 28 & 79 \\
\hline Total & 60 & 100 & 40 & 100 \\
\hline
\end{tabular}

The routes fluctuate depending on the physical and legal barriers migrants encounter. Financial capacity as well as the level and depth of connection smugglers might have with border police, immigration officers and public officials, means that one migrant can easily fly to Kenya and then transit to Mozambique or Swaziland or other neighboring countries before arriving in South Africa. Another might cross the Ethiopian-Kenyan border on foot, and continue the journey to South Africa bribing border police as well as immigration and public officials.

\section{Source of Money for transportation}

Table 7. Source of getting money for transportation and paying for traffickers

\begin{tabular}{lllll}
\hline Variables & \multicolumn{2}{l}{ Out-migrant } & \multicolumn{2}{l}{ Return migrant } \\
\hline Means of getting money & Frequency & Percent & Frequency & Percent \\
\cline { 2 - 5 } $\begin{array}{l}\text { Selling own farm land or other assets } \\
\text { Selling/renting families' farm land and/or }\end{array}$ & 31 & 10 & 2 & 5 \\
other assets & & 52 & 16 & 40 \\
From own saving & 3 & 5 & & - \\
Loan & 11 & 18 & - & 20 \\
Fiancé/husband & 9 & 15 & 14 & 35 \\
\hline
\end{tabular}

As the result in the above table shows, the families of the out migrants view that, higher proportion of youth migrants (52\%) out migrants got money from selling or giving families' farm land and/or other assets and $(40 \%)$ 
returnees showed the same cumulatively $47 \%$ got money for transportation from selling or giving families' farm land and/or other assets for rental.

\section{Causes of youth migration}

Table 8. Push and pull factor of rural youth migration

\begin{tabular}{lllll}
\hline Variables & Out-migrant & & Return migrant \\
\hline Factors for migration & Frequency & Percent & Frequency & Percent \\
\cline { 2 - 5 } Low unemployment & 30 & 50 & 19 & 47.5 \\
Family pressure & 7 & 11.7 & 6 & 15 \\
Peer pressure & 14 & 23.3 & 3 & 7.5 \\
Farm land shortage & 4 & 6.7 & 4 & 10 \\
Low wage rate & 5 & 8.3 & 8 & 20 \\
Expectation of better life in destiny & 14 & 23.3 & 8 & 20 \\
\hline
\end{tabular}

As the above table shows the leading push factor for rural youth migration is low employment opportunity in their origin $49 \%$ followed by peer pressure $(17 \%)$.

\section{Consequences of out-migration}

Table 9. Consequence during journey

\begin{tabular}{lllll}
\hline Variables & Out-migrant & & Return migrant \\
\hline Consequences of migration & Frequency & Percent & Frequency & Percent \\
\cline { 2 - 5 } Imprisonment & 17 & 28 & 12 & 30 \\
Trafficked & 2 & 3 & 5 & 12.5 \\
Beaten and robbed & 20 & 33.3 & 16 & 40 \\
Exposed to hunger & 12 & 2 & 27 & 67.5 \\
Exposed to disease/illness & 18 & 30 & 31 & 51.6 \\
Miss-treated by trafficker & 15 & 25 & 14 & 23.3 \\
\hline
\end{tabular}

During traveling to South Africa youths are facing different problems and fear. According to the result of the study, the largest proportion of migrants (49\%) youth migrants have faced exposed to disease/illness, followed by hunger (39\%) and beaten and robbed (36\%).

The FGDs of returnees said that their journeys were harsh with unexpected negative consequences. They reported that they were beaten physically, most of them noted that they did not reached South Africa on promised time and it usually took months even years to reach there. Considerable percentage of smuggled migrants were transported inside a closed container, the journey was much terrible as reported by the returnees. Hunger, vulnerability to dieses, mistreatments, human trafficking and loss of life are the common characters of irregular migration.

A study by Yordans Seifu (2015) reported that, the low social status of Ethiopian immigrants exposes them to a range of risks, one consequence of which is the violation of their individual rights. Since many immigrants from Ethiopia are unable to speak English or other South African languages, especially during the initial years of their arrival, they are unable to mediate their relations with bureaucracy easily. This means that they depend on money to 'talk' on their behalf. Indeed, the conventional and popular motto in the South African informal economy is "money talks". Hence, bribing becomes a means of survival. If an immigrant has a car but not a driving license or adequate driving skills, he 'makes-a- plan' with traffic police and drives freely.

\section{Conclusion}

The financial and material improvements of Ethiopian migrants in South Africa - evidenced and documented through remittances, different videos and photographs - is in sharp contrast to the low living standard of the population in rural area of Lemo woreda, encouraged youths to migrate to South Africa. The youth Migrants travel to South Africa with multitude of risks and discouraging challenges they encounter on the journey and in the settlement processes. Consequently, many died in transit countries before reaching South Africa. Even for many of those who arrived South Africa; it is not an easy thing to find job and income due to language and other way of life related problems.

High irregular youth migration to the South Africa is the dominant livelihood strategy for smugglers/irregular brokers. These brokers are exposing youths to severe and complex problem in South Africa both during their way to South Africa and even after they reached there. Most of rural youth migrations in South Africa from Lemo woreda are still living in shop which is closed by strong metal doors with small openings only to give goods and take the payment. They do not open the door by fearing robbers and killers.

Though there are a lot of migrants in South Africa and on the way with unsecured condition, the government of Ethiopia, South Africa and the passing countries like Kenya, Tanzania, Malawi and other countries were not doing on valuable solutions to secure the lives of these migrants and keep human right. 


\section{Recommendations}

Depending on the findings of the study the researcher proposes the following suggestions that could be implemented by government officials at different levels, other national and local leaders, religious leaders and the community at large in the study area:

- With the help of the development strategies put in place, the GOs and other development stake-holders working in the area should have to design interventions contributing to create decent work opportunities for the youths in the rural area.

- In the other way there should be pre-departure information and training guides for those youths who prefer to migrate as final decision. The pre departure information can help youths to take informed decision to move legally.

- $\quad$ The government should strongly apply the law to punish the irregular brokers/smugglers and the officials and polices who are corrupted and support the irregular migration.

- The Ethiopian government and transit agencies should have to think and create legal way for legal movement.

- The local government structure and Hadiya Development Association should connect the Diasporas in South Africa to the development of the area.

\section{REFERENCES}

Adugna Girmachew. 2019. Migration patterns and emigrants' transnational activities: comparative findings from two migrant origin areas in Ethiopia. Comparative Migration Studies

Assefa Admassie, Seid Nuru, and Tadele Ferede. 2015. The Demographic Dividend: An Opportunity for Ethiopia's Transformation. Washington D.C.: Ethiopian Economics Association and Population Bureau. Ethiopia. 2015.

Adamnesh Atnafu, Linda Oucho and Benjamin Zeitlyn. 2014. Rural-Urban Migration and Poverty in Ethiopia, Working paper 17

Balayneh Genoro.2016. Determinant Factor of Irregular Migration to South Africa and its Impact on the Society. IOSR Journal of Mathematics, Volume 12, Issue 3

Becky Carter and Brigitte Rohwerder . 2016. Rapid fragility and migration assessment for Ethiopia, Rapid Literature Review, the Institute of Development Studies, UK.2016.

Castles Hein, de Haas and Mark J. Miller. 2014. The Age of Migration International Population Movements in the Modern World. Fifth Edition. 2014.

Emerta Assaminew, Getachew Ahmed, Kassahun Aberra and Tewodros Makonnen.2010. International Migration, Remittances and Poverty Alleviation in Ethiopia: Ethiopian Economics Association (EEA) / Ethiopian Economic Policy Research Institute (EEPRI), working paper series, No. 1 /2010, Addis Ababa, Ethiopia.2010.

FAO. 2018. Ethiopian's Youth find hope in agricultural entrepreneurship, Story of Aminat Ahmed. May 2018.

Frouws, B.2015. A Certain Catalyst: an overview of the (mixed) migration and development debate with special focus on the Horn of Africa region. Nairobi: The Regional Mixed Migration Secretariat (RMMS).2015.

Habte Haile.2015. Socio-economic impacts of migration of Ethiopians to the South Africa and its implications for Ethio-South Africa relations. Addis Ababa University

ILO (International Labor Organization). 2016. World Employment and Social outlook.

ILO (International Labour Organization.2018.) The World Employment and Social Outlook:

Trends, the Labour Market Trends and Policy Evaluation Unit of the ILO Research Department.2018.

IOM .2013. Health Vulnerabilities Study of Mixed Migration flows from the East and Horn of Africa and the Great Lakes region to Southern Africa. Working paper for International Migration Report Geneva, Switzerland. 2013.

IOM. 2014. Glossary of International Migration Law 2014, International Organization for Migration. 2014.

MPI (Migration Policy Institute).2017. Tabulation of Data from the United Nations, Department of Economic and Social Affairs. 2017

Mwiti, Lee.2015. Seven of the biggest myths about South Africa and xenophobia - and how they drive attacks". Mail \& Guardian Africa. 23 April 2015.

SNNPR, Annual Statistical Abstract,2007 E.C 2014/2015.

SNNPR Education Bureau (2016/17), Education Abstract of the SNNPR, SNNP Education Bureau, Hawassa .2017.

Teshome D. Kanko, Charles H. Teller. 2010. Irregular Migration in Sub-Saharan Africa: Causes and Consequences of Young Adult Migration from Southern Ethiopia to South Africa. Addis Ababa. 2010.

Teshome D. Kanko. 2013. Irregular Migration: Causes and Consequences of Young Adult Migration from Southern Ethiopia to the South Africa. Paper Presented at the IUSSP International Population Conference 2631 Busan, South Korea. August, 2013.

Wilkinson, Kate.2015. "New York Times \& others STILL wrong on number of immigrants in S. Africa". 28 August 2015. 
Wehmhoerner, A. 2015. Lampedusa is everywhere: migrants in South Africa. FEPS Correspondent for Southern Africa Cape Town, February 2015.

Yordanos Seifu. 2015. Social Networks, Dreams and Risks: Ethiopian Irregular Migrants into South Africa, United Nations Economic Commission for Africa (UNECA) Social Development Policy Division (SDPD,) Addis Ababa.2015. 